\title{
Linalool and methyl chavicol present basil (Ocimum sp.) cultivated in Brazil
}

OLIVEIRA, R.A. de ${ }^{1 *}$, MOREIRA, I.S.1; OLIVEIRA, F.F.1

1 Universidade Estadual de Santa Cruz, Departamento de Ciências Exatas e Tecnológicas, Rodovia IlheúsItabuna, Km-16, Salobrinho, 45662-900: Ilhéus- Brasil. *rosilene@uesc.br

RESUMO: Linalol e metil-chavicol presentes em manjericão (Ocimum sp.) cultivados no Brasil. No Brasil, as espécies de Ocimum são conhecidas como ervas aromáticas e restaurativas. Nesse trabalho foi estudado a composição química dos óleos essenciais das folhas frescas e secas de manjericão (Ocimum $s p$ ) obtido por hidrodestilação e analisados por CG-FID e CG-EM. Os teores encontrados foram de 0,70\% para as folhas secas e $0,26 \%$ para as folhas frescas. Os componentes majoritários foram: Linalol $(29,50-32,26 \%)$ e metilchavicol (36,81-41,62\%). Eucaliptol também foi detectado (9,99-7,68\%). O óleo das folhas secas apresentou composição química mais complexa. Esse trabalho contribui para o conhecimento das plantas medicinais de ocorrência no Brasil.

Palavras-chave: folhas secas, folhas frescas, Lamiaceae, análise CG

ABSTRACT: In Brazil, Ocimum species are commonly known as aromatic and restorative herbs. The present research aimed to study the chemical composition of the essential oils of fresh and dry basil (Ocimum sp) leaves obtained by hydrodistillation and analyzed by GC-FID and GC-MS. The obtained yield was $0.70 \%$ for dry leaves and $0.26 \%$ for fresh leaves. The major compounds were: linalool (29.50-32.26\%) and methyl chavicol (36.81-41.62\%). Eucalyptol could also be detected (9.99-7.68\%). The oil from dry leaves presented a more complex chemical composition. This study serves to contribute to the knowledge of medicinal plants occurring in Brazil.

Key words: dry leaves, fresh leaves, Lamiaceae, CG analysis

\section{INTRODUCTION}

The Ocimum genus (Lamiaceae family) includes approximately 60 species, normally found in tropical and subtropical regions (Paton, 1992). Ocimum species have encouraged great economic interest due to their medicinal properties and aromatic chemical characteristics (Amaral et al.,1999; Werker et al.,1993), which allow their use in perfume and cosmetic industries. They are also commonly used as condiments in sausage and frozen food industries, as well as in their natural form (Martins et al., 1994). In Brazil, there are a number of Ocimum species (Gupta, 1994), which are commonly found as aromatic and restorative herbs that alleviate spasms, lower fevers, and improve digestion, in addition to being effective against bacterial infections and in the fight against intestinal parasites (Lorenzi \& Matos, 2002). In the state of Bahia, basil (Ocimum $s p$.) has been used in the treatment of fever and flu symptoms (Moreira et al., 2002). The aim of the present study is to investigate the composition of the essential oil of fresh and dry leaves of Ocimum sp., a medicinal plant commonly used by the Brazilian people and widely marketed throughout Brazil.

\section{MATERIAL AND METHODS}

\section{Plant material}

Aerial parts of Ocimum $s p$ at flowering stage were collected, at random, in August 2009 in Vila Cachoeira, located on Ilhéus-Itabuna highway, $\mathrm{Km}$ 13 , longitude $39^{\circ} 08^{\prime} 96^{\prime \prime} \mathrm{W}$ and latitude $14^{\circ} 48^{\prime} 55^{\prime \prime} \mathrm{S}$, in Ilhéus, Bahia, Brazil. The voucher specimen was deposited in the Herbarium of Univ Estadual de Santa Cruz (HUESC) under the number HUESC 10.126. The fresh leaves were dried by forced ventilation at $50^{\circ} \mathrm{C}$ (De Leo \& Cia LTDA) for 3 hours until a constant weight was reached.

\section{Essential oil}

The plant material underwent hydrodistillation using a Clevenger apparatus for 2 hours. The oil was separated by using dichloromethane, dried with

Recebido para publicação em 11/10/2011

Aceito para publicação em 23/11/2012

Rev. Bras. PI. Med., Campinas, v.15, n.2, p.309-311, 2013. 
anhydrous sodium sulfate and concentrated. The essential oil content was determined in triplicate $(\mathrm{mL}$ of oil per $100 \mathrm{~g}$ of plant material).

\section{Chromatography analysis}

The essential oils were analyzed by means of a Saturn Varian 3800 gas chromatograph (FIDdetector). This chromotograph was equipped with a VF-5ms capillary column $(30 \mathrm{~m} \times 0.25 \mathrm{~mm} \times$ $0.25 \mu \mathrm{m}$ film thickness), using helium as a carrier gas, together with a flow rate of $1.0 \mathrm{~mL} \mathrm{~min}^{-1}$, and an injection temperature of $250^{\circ} \mathrm{C}$. The column programming began at $100^{\circ} \mathrm{C}$ per min., followed by a continuous increase of $10^{\circ} \mathrm{C}$ until the temperature reached $300^{\circ} \mathrm{C}$, which was maintained for $5 \mathrm{~min}$. The sample was dissolved in $\mathrm{MeOH}$ to provide a $10 \%$ $w / v$ solution; $1 \mu \mathrm{L}$ of sample solution was injected in the split 1:10. GC-MS qualitative analyses were performed by using a Varian Chromopack 2000 MS/ MS equipped with the same VF-5ms capillary column and the same column programming. The operation mode was an electron impact of $70 \mathrm{eV}$, scan rate, 1 scan/s, mass range 40-650 Da. The trap and the transferline temperature were $200^{\circ} \mathrm{C}$ and $250^{\circ} \mathrm{C}$, respectively. The compounds were identified from their linear indices on VF-5ms column, determined based on a homologous series of $\mathrm{C}_{8}-\mathrm{C}_{26} n$-alkanes (Doolh \& Kratz, 1963), and by comparing their mass spectral fragmentation patterns with those stored in the data bank (NIST02) and in the literature (Adams, 2007).

\section{RESULTS AND DISCUSSION}

The dry leaves offer greater oil yield, $0.70 \%$, compared to that from fresh leaves, $0.26 \%$. In the essential oil from dry leaves, 13 compounds could be identified (Table 1), including $45.49 \%$ oxygenated monoterpenes, $0.45 \%$ monoterpenes, $9.74 \%$ sesquiterpenes, and $37.91 \%$ phenylpropanoides. Linalool $(29.60 \%)$ and methyl chavicol $(36.81 \%)$ proved to be the major compounds. In the essential oil from the fresh leaves, seven compounds could be identified, including $44.75 \%$ monoterpenes, $7.12 \%$ sesquiterpenes, and $41.62 \%$ phenylpropanoids. Eucalyptol was detected at the largest amount in the oils of dry leaves. The oil from dry leaves presented a greater complexity. Methyl eugenol, E-caryophyllene, bicyclogermacrene, $\beta$-guaiene, and tau-cadinol could only be observed in the oil from dry leaves. Linalool (32.26\%) and methyl chavicol $(41.62 \%)$ proved to be the major compounds, similarly to the essential oil from the dry leaves.

The difference in the chemical composition of these oils may be attributed to the process of drying the plant material. The drying process is of utmost importance for these aromatic species (Radunz et al., 2002; Corrêa et al., 2004; Costa et al., 2005), since it sets the metabolism of the plant, immobilizing the harmful enzymatic action of the existing active principles (David et al., 2006). The temperature used in the drying process of this species led to a loss of major compounds, Table 1. The heat used in the drying process was from an

TABLE 1. Composition of the essential oils of Ocimum $s p$

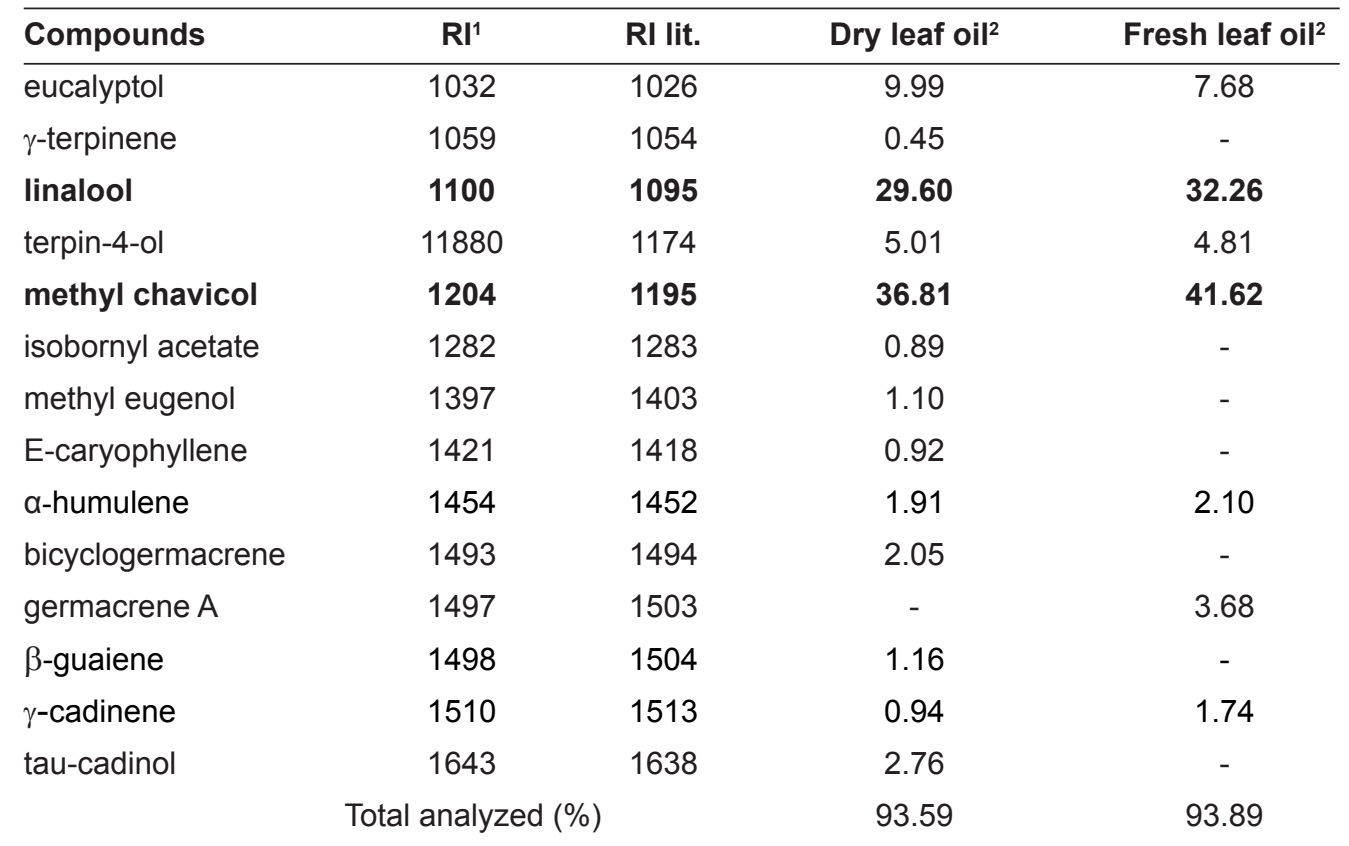

${ }^{1} \mathrm{RI}$ : Retention Index: determined with reference to homologous series of $n$-alkanes in column VF-5ms. ${ }^{2}$ Percentages were calculated by area normalization method. - not detected, Ri lit. Retention Index literature (Adams, 2007) 
energy source and thus can cause the conversion of some substances into their isomers or favor the formation of oxygenated derivatives.

Vieira \& Simon (2000), studying the essential oils of fourteen medicinal plants which were collected in Brazil and cultivated in the United States and distributed among the species 0 . americanum, O. basilicum, O. campechianum, O. gratissimum and $O$. selloi, observed variations in the chemical composition of the oils of one same species collected from different areas of Brazil, suggesting the existence of chemotypes. O. basilicum can be classified into four major essential oil chemotypes: methyl chavicol, linalool, methyleugenol and methyl cinnamate (Klimánková et. al, 2008). The chromatographic profile of essential oils of Ocimum $s p$ cultivated in Bahia shows proximity to the essential oil of $O$. basilicum species; therefore, the relationship among different forms of $O$. basilicum can be considered reticulate, whereas the group taxonomy can be considered difficult (Graeyer, et al., 1996).

There are differences in the yield and chemical composition of essential oils obtained from fresh leaves and dry leaves of Ocimum $s p$, commonly used as medicinal plants by Brazilians. Although the drying process is important for the use of medicinal plants, there is a need for further investigations to establish the best drying conditions for this species.

\section{ACKNOWLEDGEMENTS}

The authors wish to thank UESC for their financial support and FAPESB (Fundação de Amparo a Pesquisa do Estado da Bahia) for its grant for scientific initiative and DSc Alex-Alan Furtado by support in chromatography analysis.

\section{REFERENCE}

ADAMS, R.P. Identification of Essential Oils Components by Gas Chromatographyl Mass Spectroscopy. Allured: Publishing Co. Carol Stream, 4ed. 2007. 804 p.

AMARAL, J.F.T., FONSECA, A.F.A. da., MARTINEZ, H.E.P., PEREIRA, P.R.; FONTES, P.C.R. Deficiências de macronutrientes, Fe e B em manjericão (Ocimum sp.) em cultivo hidropônico. Revista Ceres, v.25, p.297308,1999.

CORREA. R.M.; BERTOLUCCI, S.K.V.; PINTO, J.E.B.P.;
REIS, E.S.; ALVES, T.L. Rendimento de Óleo essencial e caracterização organoléptica de folhas de assa-peixe submetidas a diferentes métodos de secagem. Ciência e Agrotecnologia, v.28, p.339-344, 2004.

COSTA, L.C.doB.; CORREAA, R.M.; CARDOSO, J.C.W.; PINTO, J.E.P.B.; BERTLOLUCCI, K.V.; FERRI, P.H. Secagem e fragamentação da matéria seca no rendimento e composição do óleo essencial de capimlimão. Horticultura Brasileira, v.23, p.956-959, 2005.

DAVID, E.F.S., PIZZOLATO, M., FACANALI, R., MORAIS, L.A.S., FERRI, A.F., MARQUES, M.O.M.; MING, L.C. Influência da temperatura de secagem no rendimento e composição química do óleo essencial de Ocimum selloi Benth. Revista Brasileira de Plantas Medicinais, v.8, n.4, p 66-70, 2006.

DOOLH, V.D.; KRATZ, D.J. Ageneralization of the retention index incluing linear temperature programmed gas-liquid partition chromatography. Journal of Chromatography, v.11, p.463-67, 1963.

GRAYER, R.J., KITE, G.C., GOLDSTONE, F.J., BRYAN, S.E., PATON, A.; PUTIEVSKY, E. Infraspecific taxonomy and essential oil chemotypes in sweet basil, Ocimum basilicum. Phytochemistry, v.43, n.5, p.1033-39, 1996.

GUPTA,R. Basil (Ocimum spp.) G-15 Gene Banks for medicinal and aromatic plants. Newsletter, v.1, n.5/6, p.1-3, 1994

KLIMÁNKOVÁ,E., HOLADOVÁ, K., HAJSLOVÁ, J., CAJKA, T., POUSTKA, J.; KOUDELA, M. Aroma profiles of five basil (Ocimum basilicum L.) cultivars grown under conventional and organic conditions. Food Chemistry, v.107, p. 464-72, 2008.

LORENZI, H.; MATOS, F.J.A. Plantas medicinais no Brasil: nativas e exóticas. Instituto Plantarum: Nova Odessa, 2002. 576p.

MARTINS, E.R., CASTRO, D.M.de, CASTELLANI, D.C.; DIAS, J.E. Plantas medicinais. UFV: Viçosa, 1994. 220p

MOREIRA, R.C.T., COSTA, L.C.B., COSTA, R.C.S.; ROCHA, E.A. Abordagem Etnobotânica acerca do Uso de Plantas Medicinais na Vila Cachoeira, Ilhéus, Bahia, Brasil. Acta Farmaceutica Bonaerense, v.21, n.3, p. 01-07, 2002.

PATON. A. A Synopsis of Ocimum L. (Lambiatae) in Africa. Kew Bulletin, v.47, n.3, p.430-35, 1992.

RADUNZ, L.L.; MELO, E.C.M.; BERBERT, P.A.; BARBOSA, L.C.A.; ROCHA, R.P.; GRADI, A.M. Efeitos da temperature do ar de secagem sobre a qualidade do óleo essencial de Alecrim Pimenta (Lippia sidoides cham). Revista Brasileira de Armazenamento. V.2, p.9-12, 2002

VIEIRA, R.F.; SIMON, J.E. Chemical characterization of basil ( Ocimum ssp) found in the markets and used in traditional medicine in Brazil. Economic Botany, v.54, p.207-216, 2000.

WERKER, E., PUTIEVSKY, E., RAVID, U., DUDAI, N.; KATIZIR, I. Glandular hairs and essential oil in developing leaves of Ocimum basilicum L. (Laminaceae). Annals of Botanic., v.71, p.43-50, 1993. 